\title{
MAKALAH ILMU JIWA BELAJAR PAI RAGAM BELAJAR
}

Dosen : Muhammad Arsyam, S. Pd. I, M.Pd arsyam0505@gmail.com

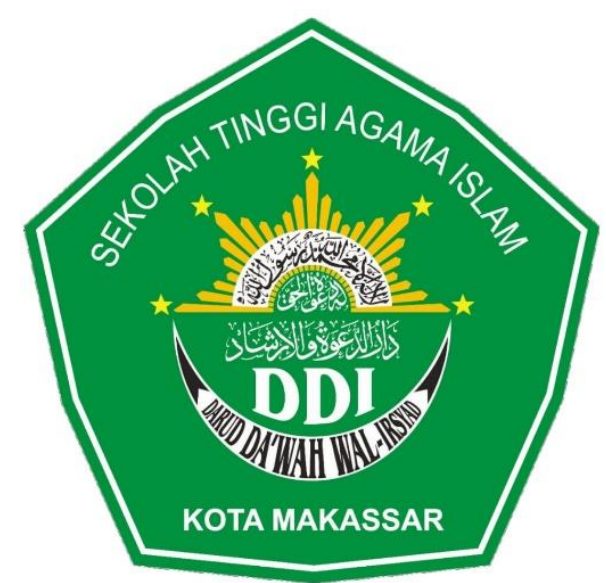

Disusun oleh

$\begin{array}{ll}\text { Nama } & \text { : Nur Hidayah / nrhidayahidris@gmail.com } \\ \text { Nim/Nimko } & : 16210017 / 8372116017 \\ \text { Nama } & : \text { Umar / umarhadykusuma02@gmail.com } \\ \text { Nim/Nimko } & : \text { 16210014/8372116014 } \\ \text { Semester } & \text { : VII (tujuh) } \\ \text { Mata Kuliah } & \text { : Ilmu Jiwa Belajar PAI }\end{array}$

\section{SEKOLAH TINGGI AGAMA ISLAM \\ DARUD DA'WAH WAL-IRSYAD \\ MAKASSAR}

2018 


\section{KATA PENGANTAR}

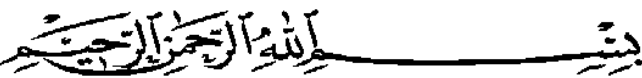

Dengan menyebut nama Allah SWT yang Maha Pengasih lagi Maha Panyayang, kami panjatkan puja dan puji syukur atas kehadirat-Nya, yang telah melimpahkan rahmat, hidayah, dan inayah-Nya kepada kami, sehingga penulis dapat menyelesaikan Makalah yang berjudul "Ilmu Jiwa Belajar PAI"..

Adapun makalah ini telah kami usahakan semaksimal mungkin dan tentunya dengan bantuan berbagai pihak, sehingga dapat memperlancar pembuatan makalah ini. Untuk itu kami tidak lupa menyampaikan bayak terima kasih kepada semua pihak yang telah membantu kami dalam pembuatan makalah ini.

Namun tidak lepas dari semua itu, kami menyadari sepenuhnya bahwa ada kekurangan baik dari segi penyusun bahasanya maupun segi lainnya. Oleh karena itu dengan lapang dada dan tangan terbuka kami membuka selebar-lebarnya bagi pembaca yang ingin memberi saran dan kritik kepada kami sehingga kami dapat memperbaiki makalah ini kedepannya.

Akhirnya penulis mengharapkan semoga dari makalah ini dapat diambil hikmah dan manfaatnya sehingga dapat memberikan inpirasi terhadap pembaca. 


\section{BAB I \\ PENDAHULUAN}

\section{A. Latar Belakang}

Salah satu masalah yang dihadapi dunia pendidikan adalah masih lemahnya proses pembelajaran. Dalam proses pembelajaran, anak kurang didorong untuk mengembangkan kemampuan. Proses pembelajaran di dalam kelas diarahkan kepada kemampuan anak untuk menghafal informasi tanpa menghubungkannya dengan kehidupan sehari-hari. Akibatnya seperti yang dikemukakan Wina Sanjaya: "Ketika anak didik lulus dari sekolah, mereka pintar secara teoritis, tetapi miskin aplikasi”.

Proses pembelajaran merupakan kegiatan fundamental dalam proses pendidikan, di mana terjadinya proses belajar tidak terlepas dari proses mengajar. Kegiatan belajar sering dikaitkan dengan mengajar, bahkan antara belajar dan mengajar digabungkan menjadi pembelajaran dan sering juga disebut dengan proses belajar mengajar. Belajar pada pihak siswa, merupakan tuntutan dasar bahkan dapat dikatakan sebagai dasar psikologis yang memungkinkan kegiatan pedagogis dan didaktis untuk berjalan sebagaimana diharapkan. Maka guru harus memahami apa hakekat dari belajar itu, apa yang dapat mempengaruhi aktivitas belajar, dan bagaimana proses belajar itu berlangsung. Sehingga guru mampu merencanakan dan menyelenggarakan proses belajar dan mengajar di dalam kelas.

Proses belajar mengajar merupakan suatu kegiatan interaksi yang dinamis antara pendidik yang melaksanakan tugas mengajar dengan anak didik yang melaksanakan kegiatan belajar. Proses interaksi ini sangat penting dalam kelangsungan proses belajar mengajar, karena dalam proses belajar mengajar pendidik menyampaikan suatu pesan berupa pengetahuan, keterampilan, sikap dan etika kepada para peserta didik melalui proses interaksi. 


\section{B. Rumusan Masalah}

1. Apa hakekat belajar?

2. Bagaimana proses belajar?

3. Apa saja ragam belajar itu?

\section{Tujuan}

1. Memahami hakekat belajar!

2. Memahami proses belajar!

3. Memahami ragam belajar! 


\section{BAB II \\ PEMBAHASAN}

\section{A. Hakekat Belajar}

Dalam keseluruhan proses pendidikan di sekolah atau perguruan tinggi, kegiatan belajar merupakan kegiatan yang paling pokok. Ini berarti bahwa berhasil tidaknya pencapaian tujuan pendidikan banyak bergantung kepada bagaimana proses belajar yang dialami oleh peserta didik.

Menurut pengertian secara psikologis, belajar merupakan suatu proses perubahan yaitu perubahan tingkah laku sebagai hasil dari interaksi dengan lingkungannya dalam memenuhi kebutuhan hidupnya. Perubahan-perubahan tersebut akan nyata dalam seluruh aspek tingkah laku. Slameto menyatakan bahwa: "Belajar adalah suatu proses usaha yang dilakukan seseorang untuk memperoleh suatu perubahan tingkah laku yang baru secara keseluruhan, sebagai hasil pengalamannya sendiri dalam interaksi dengan lingkungannya". Selanjutnya Nana Sudjana mendefenisikan: "Belajar adalah suatu proses yang ditandai dengan suatu perubahan pada diri seseorang". Perubahan yang dimaksud itu berupa hasil belajar yang dapat ditunjukkan dalam berbagai bentuk.

Berdasarkan pendapat-pendapat di atas dapat disimpulkan bahwa para ahli mendefenisikan belajar menggunakan kata "perubahan" yang berarti seseorang itu setelah belajar akan mengalami perubahan. Perubahan yang dimaksud adalah perubahan tingkah laku, baik dari aspek pengetahuan, keterampilan maupun sikap.

Adapun ciri-ciri perubahan tingkah laku dalam pengertian belajar adalah sebagai berikut:

1. Perubahan yang terjadi secara sadar, misalnya individu menyadari bahwa pengetahuannya bertambah, kecakapannya bertambah, kebiasaannya bertambah. 
2. Perubahan dalam belajar bersifat kontinu dan fungsional, misalnya seseorang yang tadinya tidak dapat menulis selanjutnya dapat menulis indah dan sebagainya.

3. Perubahan dalam belajar bersifat positif dan aktif.

4. Perubahan dalam belajar bukan bersifat sementara.

5. Perubahan dalam belajar bertujuan atau terarah.

6. Perubahan mencakup seluruh aspek tingkah laku.

Faktor-faktor yang mempengaruhi belajar, antara lain:

1. Faktor internal:
a. Faktor jasmani.
b. Faktor psikologis.
c. Faktor kelelahan.

2. Faktor eksternal:
a. Faktor keluarga.
b. Faktor sekolah.
c. Faktor masyarakat.

Adapun prinsip-prinsip dalam belajar, antara lain:

d. Agar seseorang benar-benar belajar harus mempunyai suatu tujuan.

e. Tujuan itu harus timbul dari atau berhubungan dengan kebutuhan hidupnya dan bukan karena dipaksakan orang oleh lain.

f. Harus bersedia mengalami berbagai macam kesulitan dan berusaha dengan tekun untuk mencapai tujuan yang berharga baginya.

g. Belajar itu harus terbukti dari perubahan kelakuannya.

h. Selain ingin mencapai tujuan pokok, diperoleh juga tujuan lain. 
Belajar merupakan salah satu konsep yang sangat mendasar dari psikologi. Manusia belajar untuk hidup. Tanpa belajar, seseorang tidak akan dapat mempertahankan dan mengembangkan dirinya, dan dengan belajar manusia mampu berbudaya dan mengembangkan harkat kemanusiaannya. Inti dari perbuatan belajar adalah upaya untuk menguasai sesuatu yang baru dengan memanfaatkan yang telah ada pada diri individu. Penguasaan yang baru itulah tujuan belajar dan pencapaian sesuatu yang baru merupakan tanda-tanda perkembangan, baik dalam aspek kognitif, efektif maupun psikomotorik/keterampilan.

Belajar dalam sistem pendidikan harus mempunyai sifat aktif dan terarah ynag diwujudkan dalam bentuk tujuan instruksional yang jelas dan operasional. Selanjutnya, hasil belajar adalah sebagai pengalaman hidup yang dalam kehidupan manusia penuh dengan kegiatan secara sengaja maupun tidak disengaja, terencana maupun tidak terencana atau secara tiba-tiba. Dalam hasil belajar minimal ada perubahan kesiapan terhadap yang telah dipelajari atau kesiapan atau kesiapan terhadap hal lain yang berhubungan dengan subjek yang dipelajari.

\section{B. Teori Belajar}

Pada mulanya teori-teori belajar dikembangkan oleh para ahli psikologi dan dicobakan tidak langsung kepada manusia di sekolah, melainkan menggunakan percobaan dengan binatang. Mereka beranggapan bahwa hasil percobaannya akan dapat diterapkan pada proses belajar-mengajar untuk manusia.

Pada tingkat perkembangan berikutnya, baru para ahli mencurahkan perhatiannya pada proses belajar-mengajar untuk manusia di sekolah. Penelitian-penelitiannya yang tertuang dalam berbagai teori yang berbagai macam jenisnya. Teori-teori ini kemudian dikembangkan pada suatu stadium yang berdasar atas prinsip Conditioning, yakni pembentukan hubungan stimulus dan respons. 
Sehubungan dengan uraian di atas, maka kegiatan belajar itu cenderung diketahui sebagai suatu proses psikologis, terjadi di dalam diri seseorang. Oleh karena itu, sulit diketahui dengan pasti bagaimana terjadinya. Karena prosesnya begitu kompleks, maka timbul beberapa teori tentang belajar.

\section{Macam-macam Ragam Belajar}

1. Ragam Abstrak

Ragam belajar abstrak adalah belajar yang menggunakan cara-cara berpikir abstrak. Tujuannya adalah untuk memperoleh pemahaman dan pemecahan masalah-masalah yang tidak nyata. Dalam mempelajari hal-hal yang abstrak diperlukan peranan akal yang kuat disamping penguasaan atas prinsip, konsep, dan generalisasi. Termasuk dalam jenis ini misalnya belajar matematika, kimia, kosmografi, astronomi, dan juga sebagian materi bidang studi agama seperti tauhid.

\section{Ragam Sosial}

Ragam belajar sosial pada dasarnya adalah belajar memahami masalahmasalah dan teknik-teknik untuk memecahkan masalah tersebut. Tujuannya adalah untuk menguasai pemahaman dan kecakapan dalam memecahkan masalah-masalah sosial seperti masalah keluarga, persahabatan, kelompok, dan masalah lainnya yang bersifat kemasyarakatan. Selain itu, belajar sosial juga bertujuan untuk mengatur dorongan nafsu pribadi demi kepentingan bersama dan memberi peluang kepada orang lain untuk memenuhi kebutuhannya secara berimbang dan proporsional. 


\section{Ragam Pemecahan Masalah}

Ragam belajar pemecahan masalah yaitu belajar menggunakan metodemetode ilmiah atau berpikir secara sistematis, logis, teratur dan teliti. Tujuannya ialah untuk memperoleh kemampuan dan kecakapan kognitif untuk memecahkan masalah secara rasional, lugas dan tuntas.

\section{Ragam Rasional}

Ragam belajar Rasional ialah belajar dengan menggunakan kemampuan berfikir secara logis dan rasional. Tujuannya adalah untuk memperoleh aneka ragam kecakapan menggunakan prinsip-prinsip dan konsep-konsep. Jenis belajar ini erat kaitannya dengan belajar pemecahan masalah.

\section{Ragam keterampilan}

Ragam belajar keterampilan adalah belajar dengan menggunakan gerakangerakan motorik yakni yang berhubungan dengan urat-urat syaraf dan otot-otot (neuromuscular). Tujuannya adalah untuk memperoleh dan menguasai keterampilan jasmaniah tertentu. Dalam belajar jenis ini latihan secara intensif dan teratur amat diperlukan. Termasuk dalam belajar ini misalnya belajar olahraga, musik, menari, melukis, memperbaiki benda-benda elektronik dan juga sebagian bidang studi agama seperti ibadah shalat dan haji.

\section{Ragam Kebiasaan}

Ragam belajar kebisaaan adalah proses pembentukan kebisaaan-kebisaaan baru atau perbaikan kebisaaan-kebisaaan yang telah ada. Belajar kebisaaan selain mengguanakan perintah, suri tauladan dan pengalaman khusus juga menggunakan ganjaran dan hukuman (reward \& punishment). Tujuannya agar siswa memperoleh sikap-sikap dan kebisaaan-kebisaaan perbuatan baru yang lebih tepat dan positif 
dalam arti selaras dengan kebutuhan ruang dan waktu (konstektual) serta selaras dengan norma dan tata nilai yang berlaku, baik yang bersifat religious maupun yang bersifat kultural dan tradisional. Belajar kebisaaan lebih tepat dilaksanakan dalam konteks pendidikan keluarga sebagaimana yang dimaksud oleh Undang-Undang Sistem Pendidikan Nasional tahun 2003 Bab VI Bagian keenam Pasal 27 (1). Namun demikian, tentu tidak tertutup kemungkinan penggunaan pelajaran agama sebagai sarana belajar kebisaaan bagi para siswa.

\section{Ragam Apresiasi}

Ragam belajar apresiasi merupakan belajar mempertimbangkan (judgement) arti penting atau nilai suatu objek. Tujuannya adalah agar siswa memperoleh dan mengembangkan kecakapan ranah rasa (affective skill) dimana dalam hal ini kemampuan menghargai secara tepat terhadap nilai objek tertentu, misalnya apresiasi sastra, apresiasi musik, apresiasi lukisan, benda sejarah dan sebagainya. Bidang-bidang studi yang dapat menunjang tercapainya tujuan belajar apresiasi antara lain bahasa dan sastra, kerajinan tangan (prakarya), kesenian, menggambar, dan sebagainya. Selain Bidang studi ini, bidang studi agama juga memungkinkan untuk digunakan sebagai alat pengembangan belajar apresiasi siswa, misalnya dalam hal seni baca tulis Al-Qur'an.

\section{Ragam Pengetahuan}

Ragam belajar pengetahuan ialah belajar dengan cara melakukan penyelidikan mendalam terhadap obejek pengetahuan tertentu. Studi ini juga dapat diartikan sebagai sebuah program belajar terencana untuk menguasau materi pelajaran dengan melibatkan kegiatan investigasi dan eksperimen. Tujuan belajar pengetahuan ialah agar siswa memperoleh atau menambah informasi dan pemahaman terhadap pengetahuan tertentu yang bisaanya lebih rumit dan memerlukan kiat khusus dalam mempelajarinya, misalnya dengan menggunakan laboratorium atau penelitian lapangan. 
Pencapaian keberhasilan belajar tidak hanya menjadi tanggung jawab siswa saja, tetapi guru ikut bertanggung jawab dalam menciptakan situasi yang mendorong prakarsa, motivasi siswa untuk melakukan kegiatan belajar sepanjang hayat. Karena itu, dalam mengembangkan kegiatan pembelajaran guru harus memperhatikan hal-hal sebagai berikut:

\section{Berpusat pada siswa}

Setiap siswa pada dasarnya berbeda, dan telah ada dalam dirinya minat (interest), kemampuan (ability), kesenangan (preference), pengalaman (experience) dan cara belajar (learning style) yang berbeda antara siswa yang satu dengan siswa lainnya. Oleh karena itu guru harus mengorganisasikan kegiatan pembelajaran, materi pembelajaran, waktu belajar, media dan sumber belajar, dan cara penilaian yang disesuaikan dengan karakteristik individual siswa.

\section{Pembalikan makna belajar}

Dalam konsep tradisional belajar hanya diartikan penerimaan informasi oleh peserta didik dari guru. Namun makna belajar ini harus dibalik, di mana belajar diartikan proses aktivitas dan kegiatan siswa membangun pengetahuan dan pemahaman terhadap informasi atau pengalaman. Dan pada dasarnya proses membangun pengetahuann dan pemahaman dapat dilakukan sendiri oleh siswa dengan persepsi, pikiran serta perasaan siswa.

\section{Belajar dengan melakukan}

Aktivitas siswa dalam belajar akan sangat ideal apabila dilakukan dalam kegiatan nyata yang melibatkan dirinya, terutama untuk mencari dan menemukan serta mempraktekkannya sendiri. Dengan cara ini siswa tidak akan mudah melupakan apa yang diperolehnya selama mengikuti pembelajaran. 
4. Mengembangkan kemampuan sosial, kognitif dan emosional

Dalam kegiatan pembelajaran siswa harus dikondisikan dalam suasana interaksi dengan orang lain seperti antar siswa, antara siswa dengan guru, dan siswa dengan masyarakat. Dengan interaksi yang intensif siswa akan mudah untuk membangun pemahamannya. Guru harus mendorong terjadinya sosialisasi pada diri masing-masing siswa, di mana siswa belajar saling menghormati dan menghargai terhadap perbedaan-perbedaan dan agar siswa terdorong untuk saling membangun pengertian yang diselaraskan dengan pengetahuan dan tindakannya.

\section{Mengembangkan keterampilan pemecahan masalah}

Dalam kehidupan sehari-hari setiap orang akan dihadapkan kepada berbagai permasalahan yang harus diselesaikan, sehingga diperlukan keterampilan dalam memecahkan masalah. Untuk itu seseorang harus belajar melalui pendidikan dan pengajaran. Oleh karena itu dalam proses pembelajaran perlu diciptakan situasi yang menantang kepada siswa untuk mencari dan menemukan masalah, serta melakukan pemecahan dan mengambil kesimpulan.

6. Mengembangkan kemampuan menggunakan ilmu pengetahuan dan teknologi

Ilmu pengetahuan dan teknologi diciptakan untuk memudahkan manusia dalam menjalankan kehidupannya sehingga siswa perlu mengenal dan mampu menggunakan ilmu pengetahuan dan teknologi sejak dini, serta tidak gagap terhadap perkembangan ilmu dan teknologi. Dengan demikian, kegiatan pembelajaran diarahkan untuk memberikan kesempatan dan peluang kepada siswa memperoleh informasi dari sumber belajar dan media pembelajaran yang menggunakan teknologi serta diarahkan untuk mengenal dan mampu menggunakan multi media yang dapat dapat digunakan dalam penyajian materi pembelajaran. 
7. Belajar sepanjang hayat

Dalam Islam menuntut ilmu diwajibkan bagi setiap muslim. Siswa memerlukan kemampuan belajar sepanjang hayat dalam rangka memupuk dan mengembangkan ketahanan fisik dan mentalnya, sehingga pembelajaran diarahkan agar siswa berpikir positif tentang siapa dirinya, mengenali dirinya sendiri dengan segala kelebihan dan kekurangan yang dimilikinya serta mensyukuri atas segala rahmat, nikmat serta karunia yang telah dianugerahkan Allah kepada dirinya.

8. Perpaduan kemandirian dan kerjasama

Siswa perlu diberi pengertian dan pemahaman untuk belajar berkompetisi secara sehat, bekerjasama, dan mengembangkan solidaritasnya. Hal ini perlu dikembangkan oleh guru dengan pemberian tugas-tugas individu untuk menumbuhkan kemandirian dan semangat berkompetisi maupun tugas kelompok untuk menumbuhkan kerjasama dan solidaritas. 


\section{BAB III}

\section{PENUTUP}

\section{A. Kesimpulan}

Dalam keseluruhan proses pendidikan di sekolah atau perguruan tinggi, kegiatan belajar merupakan kegiatan yang paling pokok. Ini berarti bahwa berhasil tidaknya pencapaian tujuan pendidikan banyak bergantung kepada bagaimana proses belajar yang dialami oleh peserta didik. Menurut pengertian secara psikologis, belajar merupakan suatu proses perubahan yaitu perubahan tingkah laku sebagai hasil dari interaksi dengan lingkungannya dalam memenuhi kebutuhan hidupnya

Adapun teori belajar yang pada mulanya para ahli melakukan percobaan pada dua aspek yang berbeda yakni pada binatang dan manusia. Kemudian setelah dilakukan pada dua aspek tersebut para ahli lebih memilih melakukannya pada manusia sehingga dikembangkannya pada bidang pendidikan.

Belajar sangat berperan penting dalam kehidupan manusia sehingga sedemikian menarik untuk belajar pada setiap individual, maka untuk memulainya dapat dilakukan dengan melalui ragam belajar diantaranya: ragam abstrak, ragam social, ragam pemecahan masalah, ragam rasional, ragam pengetahuan, keterampilan, kebiasaan dan apresiasi.

\section{B. Saran}

Demikianlah makalah yang dapat kami buat, sebagai manusia biasa kita menyadari dalam pembuatan makalah ini masih terdapat banyak kesalahan dan kekurangan. Untuk itu kritik dan saran yang bersifat konstruktif sangat kami harapkan demi kesempurnaan makalah ini. Semoga makalah ini bermanfaat bagi kita semua. 


\section{DAFTAR PUSTAKA}

Wina Sanjaya, Strategi Pembelajaran Berorientasi Standar Proses Pendidikan (Jakarta: Kencana, 2008), h. 1.

Slameto, Belajar dan Faktor-Faktor yang Mempengaruhinya (Jakarta: Rineka Cipta, 2003), h. 2.

Nana Sudjana, Teknologi Pengajaran (Bandung: Sinar Baru, 1989), h. 10.

S. Nasution, Didaktik Asas-Asas Mengajar (Jakarta: Bumi Aksara, 2004), h.46-47.

J. Mursell dan S. Nasution, Mengajar dengan Sukses (Jakarta: Bumi Aksara, 2000), h. 9 .

[9]W.S. Winkel, Psikologi Pengajaran (Yogyakarta: Media Abadi, 2005), h. 490.

Darwin Syah, Perencanaan Sistem Pengajaran Pendidikan Agama Islam (Jakarta: Gaung Persada Press, 2007), h. 285.

http://kumpulantugassekolahdankuliah.blogspot.co.id/2014/09/ragam-belajar.html

http://www.anekamakalah.com/2013/01/contoh-hakikat-belajar-danmengajar.html 
